\title{
Human Immunodeficiency Virus Infects Human Seminal Vesicles in Vitro and in Vivo
}

\author{
Claire Deleage, ${ }^{*}$ Marina Moreau, ${ }^{*}$ \\ Nathalie Rioux-Leclercq, ${ }^{\dagger}$ Annick Ruffault, ${ }^{\dagger}$ \\ Bernard Jégou, ${ }^{*}$ and Nathalie Dejucq-Rainsford* \\ From the Institut National de la Santé et de la Recherche \\ Médicale,* Unité 625, Institut Fédératif de Recherche 140, and \\ Centre Hospitalier Universitaire, ${ }^{\dagger}$ Université de Rennes 1, Rennes, \\ France
}

Semen represents the main vector of HIV dissemination worldwide, yet the origin of HIV in semen remains unclear. Viral populations distinct from those found in blood have been observed in semen, indicating local viral replication within the male genital tract. The seminal vesicles, the secretions of which constitute more than $60 \%$ of the seminal fluid, could represent a major source of virus in semen. This study is the first to investigate the susceptibility of human seminal vesicles to HIV infection both in vitro and in vivo. We developed and characterized an organotypic culture of human seminal vesicles to test for target cells and HIV infection, and, in parallel, analyzed the seminal vesicle tissues from HIV-infected donors. In vitro, in contrast to HIV-1 X4, HIV-1 R5 exposure induced productive infection. Infected cells consisted primarily of resident $\mathrm{CD} 63^{+}$macrophages, often located close to the lumen. In vivo, HIV protein and RNA were also detected primarily in seminal vesicle macrophages in seven of nine $\mathrm{HIV}$-infected donors, some of whom were receiving prolonged suppressive highly active antiretroviral therapy. These results demonstrate that human seminal vesicles support HIV infection in vitro and in vivo and, therefore, have the potential to contribute virus to semen. The presence of infected cells in the seminal vesicles of treated men with undetectable viremia suggests that this organ could constitute a reservoir for HIV. (Am J Pathol 2011, 179:2397-2408; DOI: 10.1016/j.ajpath.2011.08.005)

Every year, approximately 2.5 million persons become newly infected with HIV, most through heterosexual transmission (World Health Organization and United States estimates). Although semen represents the foremost vec- tor of HIV-1 dissemination, ${ }^{1}$ the precise origins of the infected leukocytes and free viral particles contaminating the seminal plasma remain unclear. Phylogenetic studies have established that HIV in semen arises from local sources within the male genital tract and/or from passive diffusion via the blood ${ }^{2-4}$ (previous references in Le Tortorec and Dejucq-Rainsford ${ }^{5}$ ). The existence of productive sources in the male genital tract is further substantiated through observations of several differences between blood and semen, including i) detection of persistent infectious HIV in the semen of $5 \%$ to $30 \%$ of men with undetectable blood viral load receiving fully suppressive antiretroviral therapy ${ }^{5-9}$; ii) higher viral load in semen in a subpopulation of treatment-naïve men ${ }^{10}$; iii) different rates, kinetics of emergence, and diversity of drug-resistant strains ${ }^{4,11,12}$; and iv) different ratio of infected versus noninfected leukocytes. ${ }^{13}$

At present, the nature of the sources of HIV in the male genital tract remains unclear. This knowledge is crucial to the understanding of the biology of HIV sexual transmission and to the design of targeted therapies for eradicating HIV from semen.

Semen is composed of secretions and cells from the testes, epididymides, prostate, seminal vesicles, and bulbo urethral glands. Vasectomy has little effect on seminal shedding of HIV-1 RNA, ${ }^{14}$ which suggests that the testes and epididymides are not the primary sources of HIV particles in semen. The seminal vesicles, the secretions of which represent more than $60 \%$ of the seminal fluid, could be an important source of seminal HIV. We recently demonstrated that the seminal vesicles of asymptomatic macaques are productively infected by simian immunodeficiency virus (SIV) in vivo and, together with the prostate, exhibit the highest level of infection among the male genital tract organs in this animal model. ${ }^{15}$ To date, infection of human seminal vesicles by HIV has not been reported.

Supported by grant 5 U42 RR006042 from the NIH and by INSERM, ANRS, Sidaction and Région Bretagne. C.D is the recipient of an ANRS stipend. M.M. is the recipient of a Région Bretagne stipend.

Accepted for publication August 2, 2011

Address reprint requests to Nathalie Dejucq-Rainsford, Ph.D., Inserm U625, Campus de Beaulieu, F-35042 Rennes, France. E-mail: nathalie. dejucq-rainsford@inserm.fr. 
To test the hypothesis that the human seminal vesicles may represent a source of virus in semen, we developed an organotypic culture of human seminal vesicle tissue to assess whether the resident immune cells or other cell types present in this organ are susceptible to in vitro infection by HIV-1 strains with different cell tropism, and searched for the presence of infected cells in the seminal vesicles in HIV-infected men and analyzed the nature of the infected cell types.

\section{Materials and Methods}

\section{Materials}

The following reagents were used: Dulbelcco's modified Eagle's medium, and RPMI 1640 medium, fetal calf serum (FCS), and glutamine (all three from Gibco-BRL, Life Technologies, Cergy-Pontoise, France), $5 \alpha$-dihydrotestosterone and phytohemagglutinin (both from Sigma-Aldrich Chimie SNC, St. Quentin Fallavier, France), penicillin-streptomycin (Eurobio Laboratories, Les Ulis, Courtaboeuf, France), IL-2 (Boerhinger-Mannheim GmbH, Mannheim, Germany), and human serum (Jackson ImmunoResearch Europe, Ltd., Newmarket, Suffolk, England). Primary antibodies, isotypic controls, and concentrations used were as follows: mouse monoclonal antibodies against HIV p24 (2 $\mu \mathrm{g} / \mathrm{mL}$, clone Kal-1), CD3 (T-lymphocyte marker, $7.3 \mu \mathrm{g} / \mathrm{mL}$, clone F.7.2.38), CD1a (Langerhans/immature dendritic cell marker, ready to use, clone 010), CD8 (20 $\mu \mathrm{g} / \mathrm{mL}, \mathrm{C} 8 / 144 \mathrm{~B}), \mathrm{HLA}-\mathrm{DR} \alpha$-chain $(1.5 \mu \mathrm{g} / \mathrm{mL}$, clone TAL.1B5), $\alpha$-actin (smooth muscle) antibody (smooth muscle cells and myofibroblasts marker, $0.1 \mu \mathrm{g} / \mathrm{mL}$, clone 1A4), cytokeratin (epithelial cell marker, ready to use, clone AE1/AE3), and Ki-67 $(0.55 \mu \mathrm{g} / \mathrm{mL}$, clone MIB-1) (all from Dako SA, Trappes, France), CD4 (2.5 $\mu \mathrm{g} / \mathrm{mL}$, clone 4B12, Novocastra Laboratories, Ltd., Newcastle-upon-Tyne, England), CD83 (mature dendritic cell marker, 1:20, clone 1H4b, Leica Biosystems Newcastle, Ltd., Newcastle-upon-Tyne, England), CCR5 (25 $\mu \mathrm{g} / \mathrm{mL}$, clone 183, R\&D Systems, Inc., Minneapolis, MN), CXCR4 (10 $\mu \mathrm{g} / \mathrm{mL}$, clone 12G5, Dr. J Hoxie, NIBSC [National Institute for Biological Standards and Control] Centralised Facility for AIDS Reagents, Potters Bar, Hertfordshire, England); and matching mouse isotypic controls IgG2a and IgG2b (R\&D Systems, Inc.), IgG1 kappa (Dako SA); rabbit polyclonal anti-CD3 $(20 \mu \mathrm{g} / \mathrm{mL}$, SigmaAldrich Chimie SNC), CD163 (monocyte/macrophage marker, ${ }^{16,17} 2 \mu \mathrm{g} / \mathrm{mL}$, K20T, Novus Biologicals, LLC, Littleton, CO), and control IgG rabbit (Jackson ImmunoResearch Europe, Ltd.). Mounting medium with DAPI was used for immunofluorescence (Vectashield; Vector Laboratories, Ltd., Peterborough, England). Secondary antibodies were either biotinylated (anti-mouse or antirabbit lgG, 1:500, Dako SA) or fluorescently labeled [goat anti-mouse Alexa Fluor $488(4 \mu \mathrm{g} / \mathrm{mL})$ or goat anti-rabbit Alexa Fluor $594(4 \mu \mathrm{g} / \mathrm{mL})$ ], Invitrogen BP, Cergy-Pontoise, France). HIV-1 clade B R5 $5_{\mathrm{SF} 162}$ and $\mathrm{X} 4_{\text {IIIB }}$ strains were obtained from the NIBSC Centralised Facility for AIDS Reagents. They were grown in peripheral blood mononuclear cells (PBMCs) stimulated using phytohem- agglutinin ( $3 \mu \mathrm{g} / \mathrm{mL}$ ) and IL-2 (5\%) or in C8166 cells (for $\mathrm{X}_{\text {IIIB }}$ ) to provide viral stocks.

\section{Organotypic Culture of Human Seminal Vesicle Explants}

The study protocol was approved by the local ethics committee, and informed consent was obtained from all donors. Normal seminal vesicles were obtained at Rennes University Hospital from patients seronegative for HIV-1 who underwent radical prostatectomy and had not received hormone treatment. Immediately after surgery, seminal vesicle tissues were placed at $4^{\circ} \mathrm{C}$ in fresh medium supplemented with antibiotics and processed within 1 hour. The absence of disease was assessed at histologic analysis. Seminal vesicles were dissected into $2 \times 2 \times 6-\mathrm{mm}$ longitudinal sections, and each section was transferred onto a polyethylene terephthalate insert in a well of a 12-well plate (Falcon Labware; Becton Dickinson \& Co., Lincoln Park, NJ) containing $1 \mathrm{~mL}$ medium (RPMI 1640 with antibiotics, 10\% fetal calf serum, and $800 \mathrm{ng} / \mathrm{mL} 5 \alpha$-dyhydrotestosterone). For each experimental condition, two wells were tested. The culture was maintained for 15 days in a humidified atmosphere containing $5 \% \mathrm{CO}_{2}$ at $37^{\circ} \mathrm{C}$, and the medium was changed every 2 days and stored frozen at $-80^{\circ} \mathrm{C}$. Every 3 days, seminal vesicle explants were either fixed in neutral buffered $4 \%$ formaldehyde or frozen and stored at $-80^{\circ} \mathrm{C}$.

\section{Immunohistochemistry and Cell Count}

Immunohistochemistry using the avidin-biotin-peroxidase complex technique was performed on formaldehydefixed, paraffin-embedded (FFPE) tissues as previously described. ${ }^{18}$ In brief, after antigen retrieval $[1 \mathrm{mmol} / \mathrm{L}$ EDTA (pH 9.0) or $10 \mathrm{mmol} / \mathrm{L}$ citrate (pH 6.0) for $20 \mathrm{~min}$ utes] and blockage of unspecific sites with $4 \%$ normal human serum in PBS, tissues were reacted at $4^{\circ} \mathrm{C}$ overnight using the appropriate antibody diluted in PBS containing $2 \%$ normal human serum. The primary antibody was replaced with the appropriate isotopic control at the same concentration in control sections. Sections were washed and reacted with a biotinylated secondary antibody at room temperature for 1 hour. After subsequent washes, the sections were incubated using the avidinbiotin-peroxidase complex (Vectastain ABC Kit; Vector Laboratories, Ltd.) for 30 minutes, and bound antibodies were visualized using aminoethyl carbazole substrate or 3,3'-diaminobenzidine (Dako SA). The nuclei were counterstained using Masson's hemalum. The sections were observed and photographed using an Axiolmager M1 (Carl Zeiss Microlmaging GmbH, Göttingen, Germany). Cell staining was never observed for istotypic controls. Cell counting was performed on tissues from a minimum of three donors using Cast software (Olympus, Lille, France). Cells that stained positive were counted at $40 x$ magnification in the total surface of one or several tissue sections per individual (minimum surface, $30 \mathrm{~mm}^{2}$ ). 


\section{Real-Time Quantitative RT-PCR}

Total RNA was extracted from the seminal vesicle explants at days 1, 9, 13, and 15 of culture using the RNeasy isolation kit (Quiagen SA, Courtaboeuf, France) and depleted of contaminating DNA via DNase treatment (Quiagen SA). CDNA was generated from $2 \mu \mathrm{g}$ total RNA using M-MLV reverse transcriptase (SuperScript II; Gibco-BRL, Life Technologies). PCR was performed on 40-ng equivalent RNA with the ABI 7500 Fast Real-Time PCR System (Applied Biosystems, Inc., Foster City, CA) using commercially available master mix and target probes (Applied Biosystems, Inc.): Hs00181217_m1 (CD4), Hs00607978_s1 (CXCR4), Hs00152917_m1 (CCR5), Hs99999901_s1 (18 S). For steroid dehydrogenase (accession No. NCBI GenBank: NM_003104.4), the following primers and probes were designed: forward, 5' -AGGATGCATTCTGTTGGAATC-3'; reverse, 5'-GCAACACGATCACCTGGTT-3'; and probe, 5'-TGGGACATGAAGCTTCGGGA-3'. The $\mathrm{C}_{T}$ value of each gene was calculated using the $A B I$ sequence detection system 1.9 program (Applied Biosystems, Inc.). The relative gene expression in a minimum of three independent cultures at various times was normalized to $18 \mathrm{~S}$ expression and calculated using the comparative $\mathrm{C}_{\mathrm{T}}$ method, as previously described. ${ }^{19}$

\section{HIV-1 Infection of Seminal Vesicle Explants}

Immediately after dissection, each explant was immersed in 200 to $500 \mu \mathrm{L}$ of a stock of HIV-1 R5 $5_{\mathrm{SF} 162}$ or $\mathrm{X} 4_{\text {IIIB }}$ cell-free viral supernatant [corresponding to 8 to $13 \mathrm{ng}$ of reverse transcriptase activity and 1 to $4 \times 10^{4} \mathrm{TCID}_{50}$ (median tissue culture infective dose)] for 3 hours (R5 ${ }_{\mathrm{SF} 162}$ and $\mathrm{X} 4_{\text {IIIB }}$ ) or overnight $\left(\mathrm{X} 4_{\text {IIIB }}\right)$ at $37^{\circ} \mathrm{C}$ and then thoroughly rinsed three times in PBS. The explants were placed in culture as described previously, and the culture medium was collected and replaced every 2 days throughout the culture.

\section{Reverse Transcriptase Activity and Infectivity Assays}

HIV-1 reverse transcriptase activity in the seminal vesicle supernatants was assayed using the Lenti-RT activity assay (Cavidi AB, Uppsala, Sweden) as previously described. ${ }^{18}$ For infectivity assay, $500 \mu \mathrm{L}$ seminal vesicle culture supernatants collected at the day of peak reverse transcriptase activity or $500 \mu \mathrm{L}$ viral stock used for infection and maintained at $37^{\circ} \mathrm{C}$ for 9 days, used here as a negative control, was ultracentrifuged for 3 hours at $39,500 \times g$. Supernatants were discarded, and the pellets were dissolved in $500 \mu \mathrm{L}$ RPMI 1640, which was added to $4 \times 10^{6}$ phytohemagglutinin-activated PBMCs for 3 hours at $37^{\circ} \mathrm{C}$. PBMCs were resuspended in $2 \mathrm{~mL}$ RPMI 1640 supplemented with 5\% IL-2 and maintained at $37^{\circ} \mathrm{C}$ for 15 days. The culture medium was changed at day 1 and then every 3 days, and was stored frozen at $-80^{\circ} \mathrm{C}$ for subsequent reverse transcriptase assay.

\section{Measurement of HIV-1 DNA Using TaqMan Real-Time PCR}

Total DNA was extracted using the QIAamp DNA Mini Kit (Quiagen SA) according to the manufacturer's instructions. Quantitative real-time PCR for HIV-1 LTR DNA and for the albumin gene used as a reference was performed on 250 ng DNA, as previously described. ${ }^{18}$ For each donor and each time point, two separate blocks of tissue were analyzed in duplicate.

\section{Immunofluorescence}

For co-localization experiments, the FFPE tissue sections were analyzed via double-color immunostaining using the antibodies described in Materials (polyclonal antibodies anti-CD163 or anti-CD3 and monoclonal antibodies against either p24 antigen, HLA-DR, CCR5, CXCR4, or CD4). Antigen unmasking was performed via 10 minutes of irradiation in a microwave oven of deparaffinized sections in $10 \mathrm{mmol} / \mathrm{L}$ citrate buffer $(\mathrm{pH} \mathrm{6)}$. Sections were incubated with primary antibodies or isotypic controls for 1 to 2 hours at room temperature or overnight at $4^{\circ} \mathrm{C}$, washed with Tris-buffered saline solution, and sequentially incubated with fluorescently labeled secondary antibodies. Cell nuclei were visualized using nuclear chromatin staining (DAPI). Slides were examined under a fluorescence microscope (Axiolmager M1; Carl Zeiss Microlmaging $\mathrm{GmbH}$ ) equipped with a charge-coupled device camera. Individual channels were collected simultaneously using computer software (AxioVision, version 4.7.1; Carl Zeiss Microlmaging $\mathrm{GmbH}$ ). The percentage of double staining was calculated by counting co-labeled cells in 200 positive cells for one marker in distinct areas of the seminal vesicle from a minimum of three donors. Data are given as the mean percentage \pm SEM of colabeled cells for the indicated number of donors.

\section{Tissue Sections from HIV-Positive Donors}

After approval of our research protocol by National Disease Research Interchange (Phildelphia, PA), seminal vesicle tissues were obtained at autopsy from HIV-infected men and underwent PFPE. Characteristics of the donors are given in Table 1.

\section{Simultaneous in Situ Hybridization and Immunohistochemical Staining}

Localization and identification of cells expressing HIV-1 RNA was performed by combining radioactive in situ hybridization for HIV-1 Gag protein and immunohistochemical staining for cell markers, as previously described. ${ }^{18}$ The specificity of the hybridization signal was systematically checked by hybridizing sense probes on parallel sections and anti-sense probes on seminal vesicles from uninfected men. 
Table 1. Characteristics of Donors Infected with HIV-1

\begin{tabular}{|c|c|c|c|c|c|c|c|}
\hline Donor & $\begin{array}{c}\text { Plasma CD4+ } \\
\text { cells } \\
\text { (count/ } \mu \mathrm{L})\end{array}$ & $\begin{array}{c}\text { Plasma HIV-1 } \\
\text { RNA } \\
\text { (copies/mL) }\end{array}$ & $\begin{array}{l}\text { Duration of } \\
\text { HIV-1 infection } \\
\text { (years) }\end{array}$ & Co-infections & ARV & Cause of death & $\begin{array}{l}\mathrm{P}_{2} 4^{+} \text {cells } \\
\text { in SV* }\end{array}$ \\
\hline 85 & NA & 139,000 & NA & $\mathrm{HCV}$ & NA & AIDS & 2.20 \\
\hline 108 & $<20$ & 51,681 & NA & $\mathrm{HCV} / \mathrm{HBV}$ & Combivir, Sustiva & AIDS & 0.24 \\
\hline 111 & $\begin{array}{r}134 \\
1 \text { month }^{\dagger}\end{array}$ & $\begin{aligned}<50 & <\text { month }^{+}\end{aligned}$ & NA & $\mathrm{HCV}$ & Atripla & Lymphoma & 0 \\
\hline 110 & 1 week $^{219}$ & $\begin{array}{c}<50 \\
1 \text { week }^{\dagger} \text { (for } \\
4 \text { years })^{2}\end{array}$ & 17 & None & $\begin{array}{c}\text { Oxanadol, Itellence, } \\
\text { Prezista, Viread, } \\
\text { Isentress, Norvir }\end{array}$ & $\begin{array}{l}\text { End-stage renal } \\
\text { disease }\end{array}$ & 0.12 \\
\hline 112 & $\begin{array}{r}256 \\
1 \text { month }^{\dagger}\end{array}$ & $\begin{array}{r}<50 \\
1 \text { month }^{+}\end{array}$ & 26 & HBV & $\begin{array}{l}\text { Tenofovir, Epivir, } \\
\text { Abacavir, Trizivir }\end{array}$ & Liver cancer & 0.97 \\
\hline 103 & 269 & $\begin{array}{c}<50 \text { (for } 5 \\
\text { years) }\end{array}$ & NA & $\mathrm{HCV} / \mathrm{HBV} / \mathrm{HTLV}$ & $\begin{array}{l}\text { Tenofovir, Sustiva, } \\
\text { Ziagen, Epivir }\end{array}$ & Nephropathy & 0.61 \\
\hline 107 & 1 day $^{+437}$ & $\begin{array}{l}<50 \\
1.5 \text { month }^{\dagger} \\
\text { (previous }^{-} \\
\text {AIDS) }\end{array}$ & 17 & $\mathrm{HCV} / \mathrm{HBV}$ & $\begin{array}{l}\text { Epzicom, Reyataz, } \\
\text { Norvir }\end{array}$ & $\begin{array}{l}\text { Respiratory failure } \\
\text { due to pneumonia }\end{array}$ & 0.04 \\
\hline 139 & $\begin{array}{r}495 \\
2 \text { months }^{\dagger}\end{array}$ & $\begin{array}{r}<50 \\
4 \text { months }^{\dagger}\end{array}$ & 20 & None & Atripla & Myocardial infarction & 0 \\
\hline 92 & $\begin{array}{r}1076 \\
2 \text { months }^{\dagger}\end{array}$ & $\begin{array}{r}<50 \\
4 \text { months }^{\dagger}\end{array}$ & NA & $\mathrm{HCV} / \mathrm{HBV}$ & $\begin{array}{l}\text { Truvada (stopped } \\
1 \text { week before } \\
\text { death) }\end{array}$ & Adenocarcinoma & 0.74 \\
\hline
\end{tabular}

\section{Statistical Analysis}

The significance of the differences or correlation between values was evaluated using the appropriate nonparametric test, as specified in the text or in the figure legends. $P<$ 0.05 was considered statistically significant. Statistical analyses were performed using commercially available software (SAS version 9.1.3; SAS Institute, Inc., Cary, NC).

\section{Results}

\section{Characterization of Human Seminal Vesicles in Organotypic Culture}

The architecture and expression of seminal vesicle cell markers were compared in seminal vesicle explants before culture and throughout the culture period. Histologic examination of seminal vesicle fragments revealed that the tissue architecture was maintained throughout the 15-day culture period (Figure 1, A-D). Columnar epithelial cells retained their height up to day 5 (Figure 1, B versus $A$ ), and began to flatten therafter (Figure 1, C and D). Positive staining for cytokeratin observed for the pseudo-stratified epithelium before culture was maintained until the end of culture at day 15 (Figure 1, E and F). Similarly, quantification of the transcript-encoding steroid dehydrogenase, an enzyme produced by seminal vesicle epithelial cells, demonstrated expression of this cell marker throughout the culture period (Figure 1K). Stromal cells were still abundant at day 11 of culture (Figure 1, C versus A), with only a few patchy losses (data not shown), whereas a more generalized decrease was observed at day 15 (Figure 1D). Positive staining for $\alpha$-actin, a marker of smooth muscle cells and myofibroblasts, was observed in the stroma before and at the end of the 15-day culture period (Figure 1, G and $\mathrm{H}$ ). In the explants before culture, only a small number of cells were proliferating, as indicated by the detection of Ki-67 (Figure 11). The number of cells increased only slightly during culture, primarily at the epithelial level (Figure 1J).

\section{Detection and Quantification of Potential HIV-1 Target Cells in Human Seminal Vesicles}

Cells that stained positive for the monocyte/macrophage marker CD163, the T-lymphocyte marker CD3, and the HIV receptor CD4 were evident within the fixed seminal vesicle tissues from all donors before and during culture (Figure 2A). CD163 ${ }^{+}$cells were observed both in the stroma and inserted, or close to, the epithelium, whereas $\mathrm{CD}^{+}$cells were primarily concentrated within the stroma. In contrast, $\mathrm{CD} 8^{+}$cells were consistently observed, primarily inserted within the epithelium and rarely in the stroma (Figure 2A). Some rare cells stained positive for CD83, a marker of mature dendritic cells, whereas no staining was observed for CD1a, a marker of Langerhans/immature dendritic cells (data not shown). The HIV co-receptors CCR5 and CXCR4 (Figure 2A) were detected in cells with immune cell-type morphologic features, whereas no staining was present on epithelial cells. Quantitative immunohistochemistry revealed that the seminal vesicle contained primarily $\mathrm{CD}_{163^{+}}$macrophages and, to a lesser extent, $\mathrm{CD}^{+} \mathrm{T}$ lymphocytes and $\mathrm{CD} 4^{+}$cells, whereas stromal $\mathrm{CD}^{+}$cells were scarce (Figure 2B). Cells staining positive for CCR5 were far more abundant than those staining positive for CXCR4 (Figure 2B). To assess the nature of $\mathrm{CD}_{4}^{+}, \mathrm{CCR}^{+}$, and $\mathrm{CXCR} 4^{+}$cells, double labeling was performed (Figure 2C). CD4 staining co-localized with $\mathrm{CD}^{+} \mathrm{T}$ lymphocytes but not with $\mathrm{CD} 163^{+}$macrophages (Figure $2 \mathrm{C}$ ), in line with the known low level of CD4 


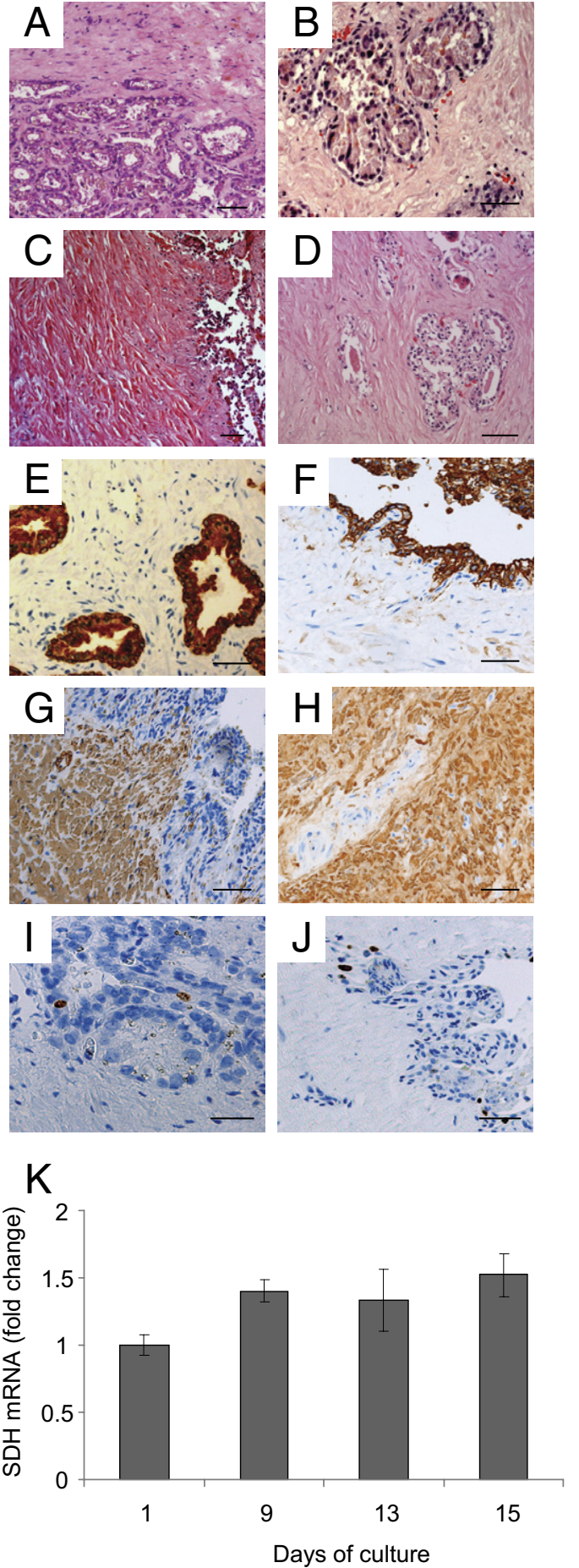

Figure 1. Characterization of human seminal vesicles in organotypic culture. A-H: PFPE sections were examined morphologically (A-D) or immunostained for several seminal vesicle cell markers $(\mathbf{E}-\mathbf{J})$ before $(\mathbf{E}$ $\mathbf{G}$, and $\mathbf{I})$ and after 15 days $(\mathbf{F}, \mathbf{H}$, and $\mathbf{J})$ of culture. The overall architecture of the organ was preserved throughout the culture (A, day 0; $\mathbf{B}$, day 5; $\mathbf{C}$, day $11 ; \mathbf{D}$, day 15$)$. The markers used for characterization of seminal vesicle cell types were cytokeratin for epithelial cells (E and $\mathbf{F}), \alpha$-actin (smooth muscle) and myofibroblastic cells ( $\mathbf{G}$ and $\mathbf{H})$, and Ki-67 for proliferating cells (I and $\mathbf{J}$ ). K: The level of expression during the culture period of the transcript encoding SDH, an enzyme produced by seminal vesicle epithelial cells, was analyzed using real-time PCR and compared with control (day 1 of culture). The results represent the mean \pm SD of a minimum of three independent cultures performed on seminal vesicles from three different donors (Kruskal-Wallis test, ${ }^{*} P<0.05$; control, day 1 ). Scale bars $=50 \mu \mathrm{m}$ expression on macrophages. ${ }^{20}$ CCR5 co-localized with $\mathrm{CD} 163^{+}$macrophages and co-labeled with $48.25 \% \pm$ $27.8 \%$ (mean $\pm \mathrm{SEM} ; n=4$ donors) of $\mathrm{CD}^{+} \mathrm{T}$ lymphocytes (Figure $2 \mathrm{C}$ ), whereas CXCR4 was exclusively detected in T lymphocytes (Figure 2C).

Using real-time RT-PCR, we quantified the persistence during culture of the expression of transcripts encoding HIV receptors CD4, CCR5, and CXCR4. CD4 mRNA copy numbers were maintained throughout the culture period, and only a slight decrease was observed at day 15 (Figure 3). CCR5 transcript copy number also demonstrated good maintenance up to day 13 , whereas a decrease was observed at day 15. In contrast, although expressed throughout the culture period, CXCR4 mRNA expression decreased from day 9 onward, and was significantly lower at days 13 and 15 compared with day 1 (Figure 3).

\section{Infection of Seminal Vesicle Explants with HIV-1 R5 or X4 Strains}

After incubation of $\mathrm{R}_{\mathrm{SF} 162}$ with seminal vesicle explants from six donors, a significant increase in reverse transcriptase activity was consistently observed between days 9 and 11 (Figure 4A). In contrast, in supernatants of seminal vesicle tissues from matched patients exposed to $X 4_{\text {IIIB }}$, no increase in reverse transcriptase activity was detected during the 15-day culture period (Figure 4A), irrespective of the duration of exposure (3 hours or overnight) and viral stock ( $\mathrm{X} 4_{\text {IIIB }}$ grown in PBMCs or in the C8166 cell line). In line with this, the viral particles obtained by ultracentrifugation of $\mathrm{R}_{\mathrm{SF} 162}$-exposed seminal vesicle supernatants productively infected activated PBMCs, whereas the ultracentrifuged supernatants from $\mathrm{X} 4_{\text {IIIB }}$-exposed seminal vesicle cultures did not lead to any detectable PBMC infection (Figure 4B).

The accumulation of HIV DNA within the seminal vesicle explants exposed to either $\mathrm{R} 5_{\mathrm{SF} 162}$ or $\mathrm{X} 4_{\mathrm{IIIB}}$ was quantified using real-time PCR (Figure $4 \mathrm{C}$ ). After exposure to $\mathrm{R} 5_{\mathrm{SF} 162}$, the HIV-1 DNA level increased almost 30-fold during culture, demonstrating productive infection. In contrast, no HIV DNA increase was observed in seminal vesicle explants exposed to $X 4_{\text {IIIB }}$.

\section{Localization and Characterization of HIV-1 p24 Cells in Human Seminal Vesicle Explants}

HIV-infected cells were localized in the explants by immunohistochemistry for the viral protein p24 (Figure 5A). HIV p $24^{+}$cells were found in the stroma and close to the epithelium of seminal vesicles exposed to HIV-1 R5 $5_{\mathrm{SF} 162}$. In contrast, no infected cells were evident in explants exposed to HIV-1 X $4_{\text {IIIB }}$ (data not shown). Double staining for p24 and either the macrophage marker CD163 or the lymphocyte marker CD3 in HIV R5-infected explants demonstrated that the vast majority of $\mathrm{p}^{2} 4^{+}$cells colabeled with CD163 (Figure 5B), whereas labeling with CD3 was observed much less frequently (Figure $5 C$ ). 

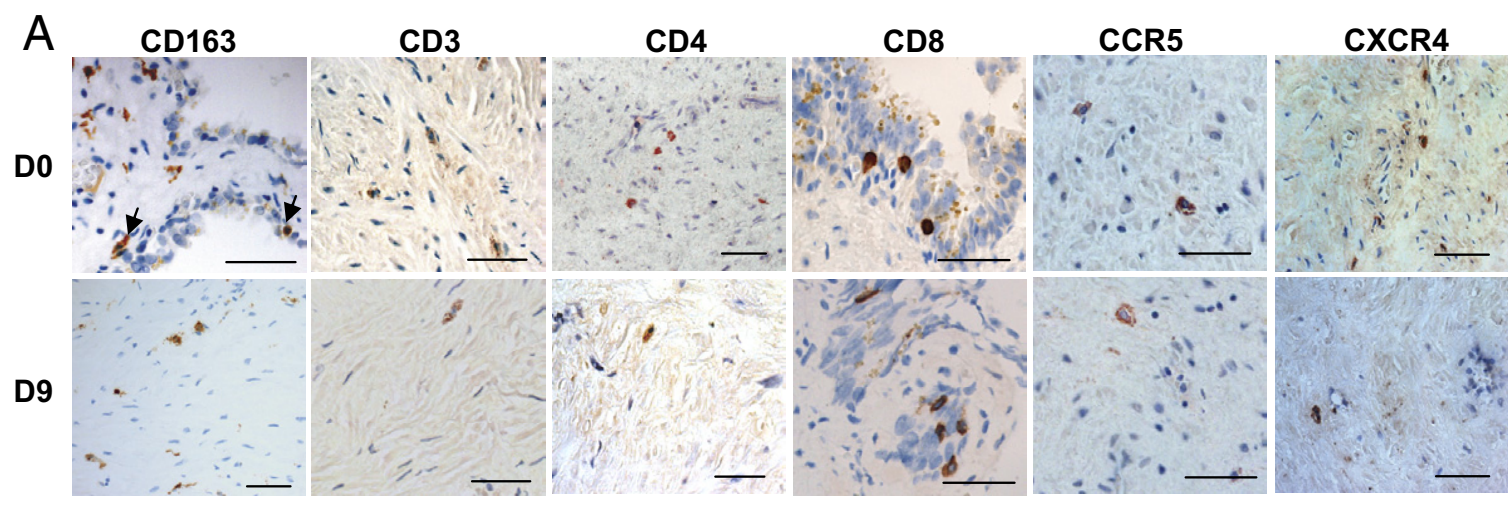

$\mathrm{B}$
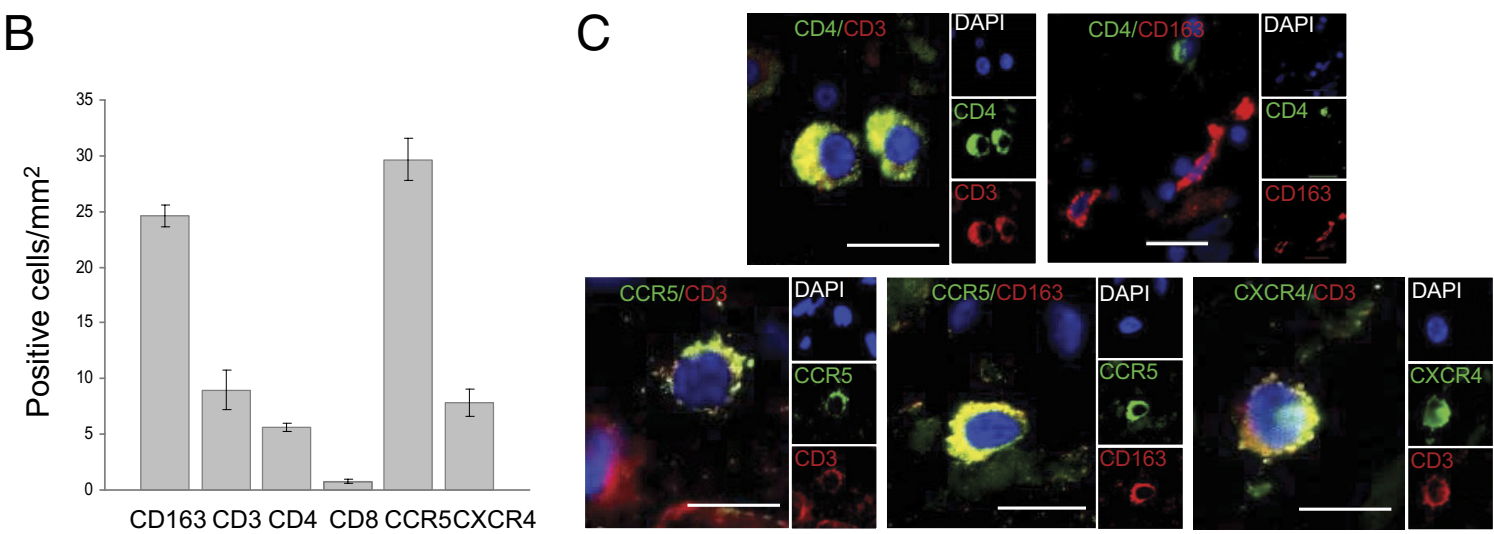

Figure 2. Analysis of potential HIV target cells in uninfected seminal vesicles. A: Immunohistochemistry performed on uninfected seminal vesicle sections before and during culture (day 9) demonstrated the presence of scattered stromal cells staining positive for CD163, CD3, CD4, CCR5, and CXCR4. CD163 ${ }^{+}$cells were also observed in close contact with epithelial cells (arrows). $\mathrm{CD}^{+}$cells were found primarily at the level of the epithelium. Scale bars $=20 \mu \mathrm{m}$. B: Respective percentages of $\mathrm{CD} 8^{+}, \mathrm{CD}^{+}, \mathrm{CD}^{+}, \mathrm{CD}^{+}, \mathrm{CCR}^{+}$, and CXCR $4^{+}$cells per surface unit before culture were evaluated in seminal vesicle sections from five donors Results represent the mean number of positive cells \pm SEM. C: HIV receptors bearing cells $\left(\mathrm{CD} 4^{+}\right.$, CXCR $4^{+}$, and CCR $\left.5^{+}\right)$were characterized by double labeling with either CD3 (T-lymphocyte marker) or CD163 (macrophage marker). Nuclei labeled with DAPI are shown (blue). Large panel represents a merged image combining all channels. Side panels represent individual channels. Scale bars $=10 \mu \mathrm{m}$.

\section{Analysis of Seminal Vesicles from HIV-Infected Men}

Fixed seminal vesicle tissues from nine deceased HIV-infected men were obtained at autopsy. Donor characteristics

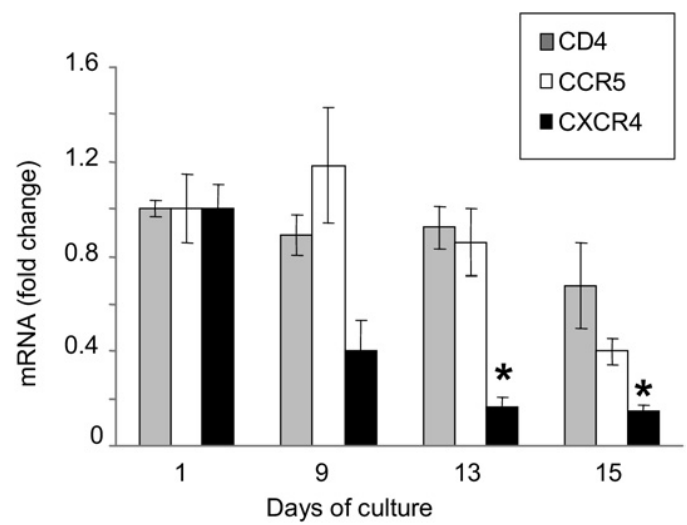

Figure 3. Real-time RT-PCR quantification of transcripts encoding HIV receptor CD 4 and co-receptors CCR5 and CXCR4 in seminal vesicle explants during culture. The relative copy number of the cDNA of interest is standardized to the copy number of the ubiquitous $18 S$ housekeeping gene cDNA and expressed relative to control (day 1 of culture). Results represent the mean $\pm \mathrm{SD}$ of three independent experiments corresponding to three donors (Kruskal-Wallis test, ${ }^{*} P<0.05$; control, day 1 ). are given in Table 1. All HIV-infected donors had received highly active antiretroviral therapy (HAART) and seven of nine had a blood viral load below the detection threshold of 50 copies per milliliter at the last measurement before death (Table 1). Seven of nine donors were co-infected with hepatitis $\mathrm{C}$ virus ( $\mathrm{HCV}$ ), hepatitis B virus (HBV), or both, and one was also positive for human T-lymphotropic virus. Histologic examination of the seminal vesicles indicated normal architecture (data not shown). HIV p24 ${ }^{+}$ cells were detected in the seminal vesicles of seven of nine donors (Table 1 and Figure 6A). In situ hybridization for HIV Gag RNA confirmed the presence of infected cells in the seminal vesicles from these patients (Figure 6B). Most HIV Gag RNA-positive cells co-localized with CD163 staining (Figure 6B). Double immunostaining for HIV p $24^{+}$cells and cell markers further demonstrated that infected cells co-localized primarily with $\mathrm{CD}_{163^{+}}$ macrophages, and evidenced co-localization of HIV p24 with a few $\mathrm{CD}^{+} \mathrm{T}$ lymphocytes in six of seven patients (Figure 6, C and D). Quantification of potential HIV target cells (ie, macrophages and activated CD4 ${ }^{+} \mathrm{T}$ cells) in seminal vesicles revealed a heterogeneous distribution of $\mathrm{CD}^{+}, \mathrm{CD}^{+}, \mathrm{CD}^{+} 163^{+}$, and HLA-DR ${ }^{+}$cells among HIVinfected patients compared with uninfected men (Figure 7). The median number of $\mathrm{CD}_{163^{+}}$macrophages was sig- 

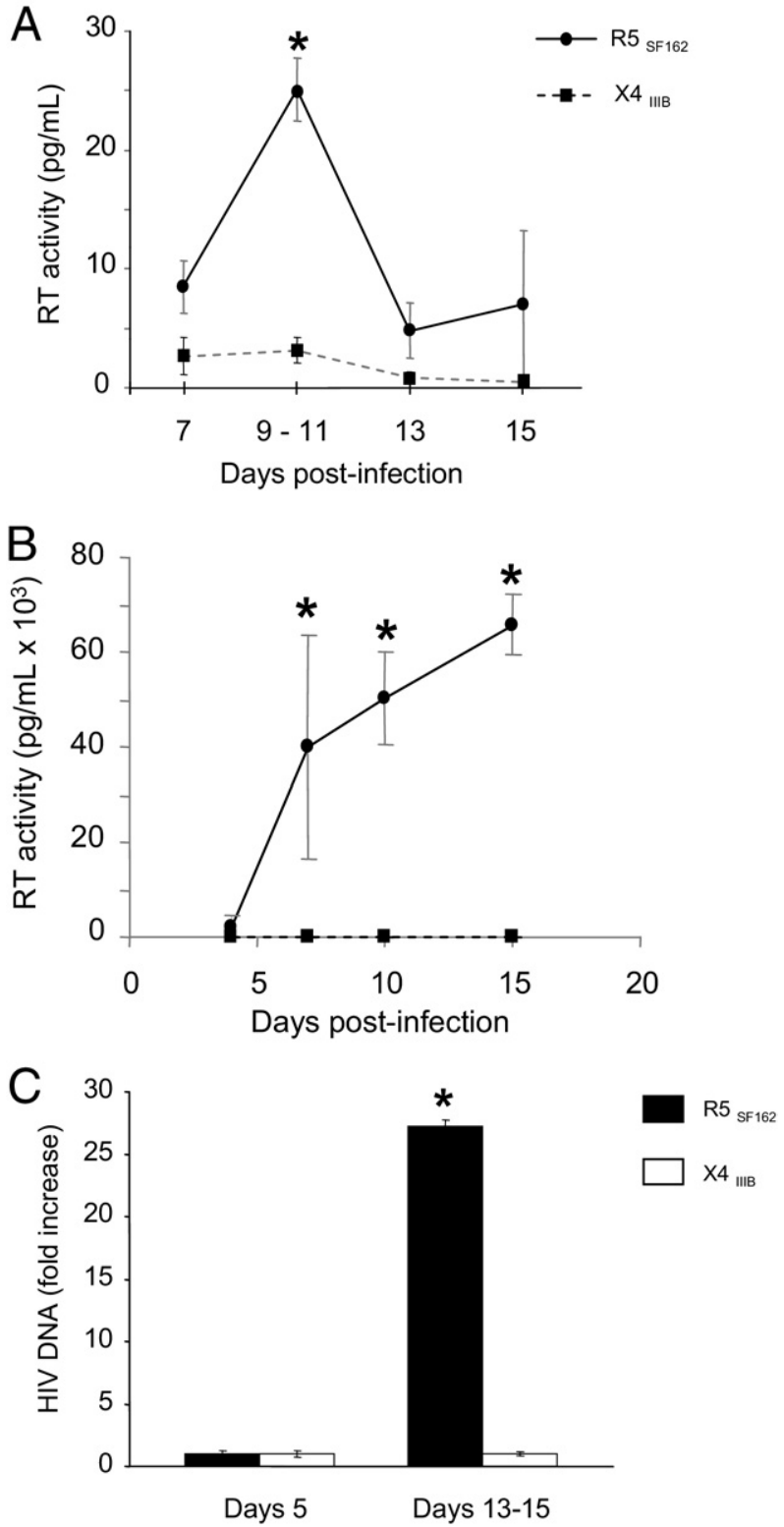

Figure 4. HIV-1 R5 $5_{\mathrm{SF} 162}$ and $\mathrm{X} 4_{\mathrm{IIIB}}$ infection of human seminal vesicles in organotypic culture. A: Reverse transcriptase activity measured in supernatants of human seminal vesicle explants demonstrated a significant increase between days 9 and 11 after exposure to HIV-1 R5 ${ }_{\mathrm{SF} 162}$ (circle, black line), whereas no increased reverse transcriptase activity was detected after exposure to $\mathrm{HIV}_{\text {IIIB }}$ (square, dotted line) ( $n=6$ donors in each case). B: Activated PBMCs exposed to supernatants of $\mathrm{R}_{\mathrm{SF} 162}$ infected explants collected at peak of reverse transcription demonstrated increased reverse transcriptase activity in the supernatants during culture $(n=3)$, whereas no increase was observed after exposure of activated PBMCs to X4 $4_{I I I B}$-infected seminal vesicle supernatants collected at different times during culture $(n=3$; data shown for day 9). C: Accumulation of HIV-1 DNA in seminal vesicle explants between days 5 and 13 to 15 after exposure to either HIV-1 $\mathrm{R} 5_{\mathrm{SF} 162}$ or $\mathrm{X}_{\mathrm{IIIB}}$, as assayed for LTR DNA using quantitative real-time PCR. For each virus, six different explants from six donors were tested. Results represent the mean \pm SEM $\left[\right.$ Mann-Whitney test, ${ }^{*} P<0.05$; control, day 7 (A), day 4 (B), and day $5(\mathbf{C})$ ].

nificantly increased in the seminal vesicles of HIV-infected compared with uninfected men (Figure 7). In contrast, despite a slightly decreased median value, there was no statistically significant difference in the number of $\mathrm{CD}^{+}{ }^{+}$and $\mathrm{CD}^{+}{ }^{+}$cells in HIV-infected donors versus un- infected donors (Figure 7). Of note, in three HIV-infected patients, $\mathrm{CD}^{+}$and $\mathrm{CD}^{+}$cell numbers were either low (two patients) or undetectable (one patient). Most $\mathrm{CD}^{+}$ cells co-localized with CD4 labeling (mean \pm SEM, $71.2 \% \pm 29.1 \% ; n=7$ donors). Whereas $80 \% \pm 28.5 \%$ of $\mathrm{HLA}^{-D R^{+}}$cells co-labeled with $\mathrm{CD} 163^{+}$macrophages ( $n=9$ donors), only $18.5 \% \pm 6.5 \%$ of $\mathrm{HLA}^{-\mathrm{DR}^{+}}$cells co-labeled with $\mathrm{CD}^{+}$( $n=9$ donors). No correlation was found between the number of HIV p24 ${ }^{+}$cells and the number of $\mathrm{CD}^{+}$cells in plasma or in the seminal vesicles (nonparametric Spearman's test, $P<0.05$ ). Similarly there was no correlation between the number of HIV $\mathrm{p} 24^{+}$cells in the seminal vesicles and the number of $\mathrm{CD}^{+}{ }^{+}$T lymphocytes, HLA-DR ${ }^{+}$cells, and macrophages (nonparametric Spearman's test, $P<0.05$ ).

\section{Discussion}

The present study highlights the seminal vesicles as a possible source of HIV in semen inasmuch as for the first time, seminal vesicle infection was evident both in vitro and in HIV-infected men. Paradoxically, while they are the major quantitative contributors to the seminal fluid, the seminal vesicles have been the least studied of the male genital organs, both in the context of HIV infection and insofar as their immunobiology. Indirect arguments that suggest that the seminal vesicles represent an important contributor to HIV shedding in semen are that selective sampling of genital fluids from HIV-positive men and prostate biopsy specimens indicated distal genitourinary sources other than the prostate gland (ie, seminal vesicles, urethra, and/or associated glands) as the major sources of seminal HIV in men without urethritis or prostatitis, ${ }^{21}$ and in animal models, seminal vesicle infection by SIV was detected in rhesus macaques with AIDS $^{22,23}$ and in asymptomatic cynomolgus macaques. ${ }^{15}$ To date, HIV infection of human seminal vesicles has not been reported. The only data available are from an early study of patients with AIDS that failed to detect HIV nucleic acids in the seminal vesicles of the three individuals tested using in situ PCR. ${ }^{24}$

Based on our experience of human male genital tract tissue culture, ${ }^{18,25,26}$ we developed an organotypic culture of the human seminal vesicles to study the intrinsic susceptibility of this organ to infection by HIV-1 strains with different co-receptor requirements, CCR5 or CXCR4. Our study revealed that the overall structure of the organ, as well as all of the cell types observed before culture, were maintained during the 15-day culture period. Of note, in contrast to expression of HIV receptor CD4 and co-receptor CCR5 mRNA, which were still strongly expressed at the end of the culture period, a decline in expression of the transcript encoding the HIV co-receptor CXCR4 was observed from day 9 onward, although it was still expressed throughout the culture. Insofar as HIV potential target cells, seminal vesicles encompassed primarily resident macrophages bearing the CCR5 co-receptor, located either within the stroma, close to the base of the epithelium, or occasionally inserted between epithelial cells. As previously reported in uninfected men ${ }^{27}$ 

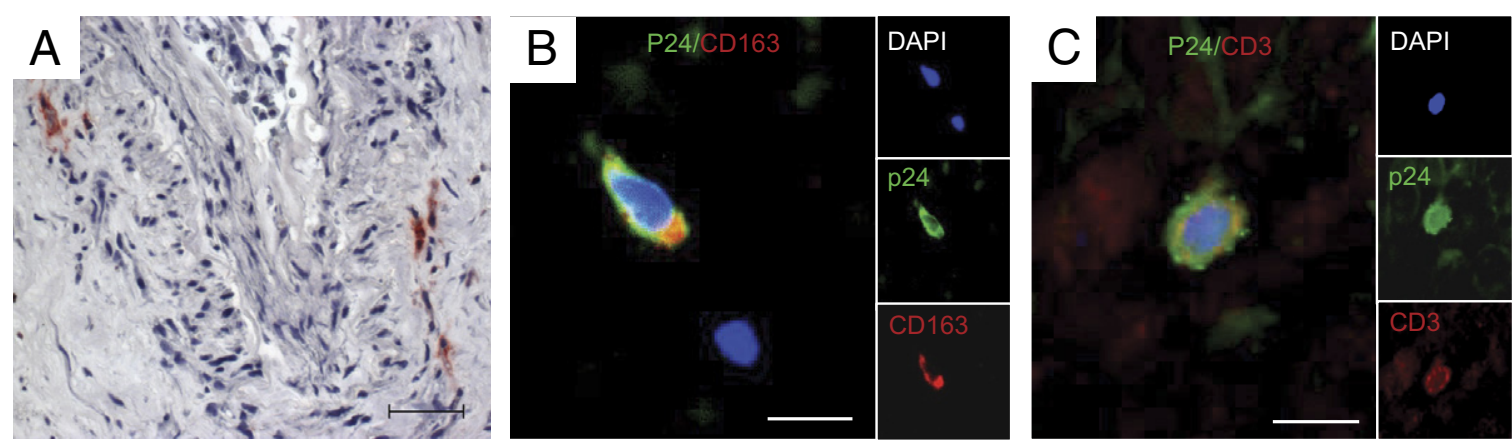

Figure 5. Localization and characterization of HIV p24-positive cells in human seminal vesicles infected in vitro. A: Localization of cells positive for HIV-1 (red) within seminal vesicle explants infected for 9 days with $\mathrm{R} 5_{\mathrm{SF} 162}$, as detected using immunohistochemistry for the capsid protein p24. B: Double immunostaining for p24 (green) and cell markers CD163 (red) (B) or CD3 (red) (C) was performed to determine the nature of the infected cells. Nuclei labeled with DAPI are shown in blue. Large panel represents a merged image combining all channels. Side panels represent individual channels. Scale bars $=50 \mu \mathrm{m}$.

and macaques, ${ }^{15,23} \mathrm{~T}$ lymphocytes were much less frequently observed than were macrophages. $\mathrm{CD}^{+}{ }^{+} \mathrm{T}$ helper cells were primarily detected in the stroma, whereas $\mathrm{CD}^{+}$cells were observed almost exclusively at the epithelial level, in agreement with earlier findings that characterized these latter cells as cytotoxic T lymphocytes. ${ }^{28}$ The pseudostratified columnar epithelium of the seminal vesicles did not exhibit detectable levels of the HIV receptors CD4, CCR5, and CXCR4 using immunohistochemistry, unlike monostratified polarized epithelia (gastrointestinal, genital, and mammary), which express CCR5 and/or CXCR4 and can transcytose or endocytose HIV. ${ }^{29,30}$ However, a low level of expression of those chemokine receptors and/or expression of alternative receptors for HIV binding/entry such as heparan sulfate or galactosylceramide cannot be ruled out.

We next tested human seminal vesicle infection by two prototypic HIV-1 strains, $\mathrm{R} 5_{\mathrm{SF} 162}$ and $\mathrm{X} 4_{\text {IIIB }}$. These strains were chosen because of their distinct and well-characterized co-receptor usage (CCR5 versus CXCR4) and tropism (macrophage tropic versus non-macrophage tropic). Such prototypic non-primary R5 and X4 strains have been widely used to test the susceptibility to HIV infection of a range of tissues including the cervix, prostate gland, foreskin, and penis. ${ }^{26,31-35}$ With use of these two strains, we demonstrated that the human seminal vesicles are selectively infected by macrophage-tropic HIV-1 R5 ex vivo and release infectious virions. The $\mathrm{R} 5_{\mathrm{SF} 162}$ strain consistently replicated in the seminal vesicle tissues, as assessed by increased reverse transcriptase activity in seminal vesicle supernatants during culture, increased level of viral DNA in the explants, PBMC infection by the viral particles recovered from the infected seminal vesicle supernatants, and in situ detection of infected cells in the explants using immunohistochemistry for HIV p24. HIV R5-infected cells were primarily macrophages, whereas only a small number of infected $T$ lymphocytes were observed. This is in line with the higher number of $\mathrm{CCR}^{+}$macrophages over CCR5 ${ }^{+}$T lymphocytes detected in the seminal vesicles. That infected macrophages were often observed close to the epithelium suggests that viral particles can be released in the
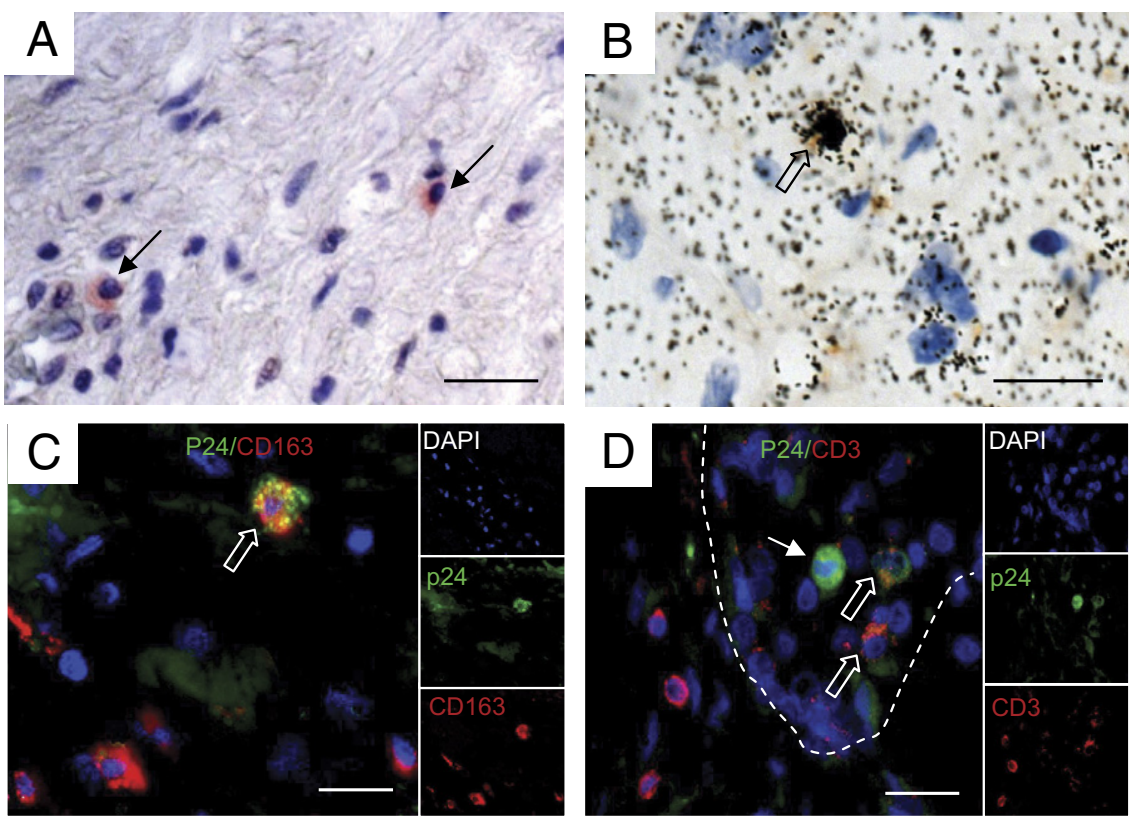

Figure 6. Localization and characterization of HIV-infected cells in seminal vesicles from HIVpositive donors. PFPE sections of seminal vesicles obtained at autopsy of HIV-infected donors were examined for the presence of HIV-infected cells using immunohistochemistry for HIV p24 (A) and in situ hybridization for HIV Gag RNA (B). Small arrows in $\mathbf{A}$ indicate infected $\mathrm{p} 24^{+}$ cells. The open arrow in $\mathbf{B}$ indicates an infected HIV $\mathrm{RNA}^{+}$cell co-localized with CD163 cell marker. Immunophenotyping of $\mathrm{p}^{2} 4^{+}$cells (green) using either CD163 (C) or CD3 (red) (D) demonstrated the presence of infected macrophages and T lymphocytes. Nuclei labeled with DAPI are shown (blue). Large panel represents a merged image combining all channels. Side panels represent individual channels. In $\mathbf{C}$ and $\mathbf{D}$, open arrows indicate co-labeled cells; the small arrow in $\mathbf{D}$ indicates an infected cell in the lumen of the seminal vesicle epithelium (shown with dotted lines) that did not co-localize with CD3. Scale bars $=50 \mu \mathrm{m}$. 
CD163
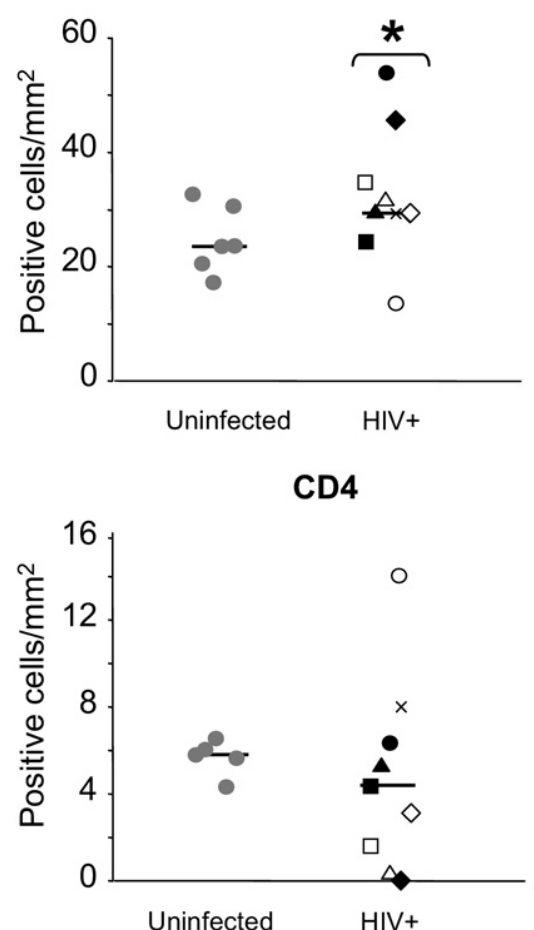

HLA-DR

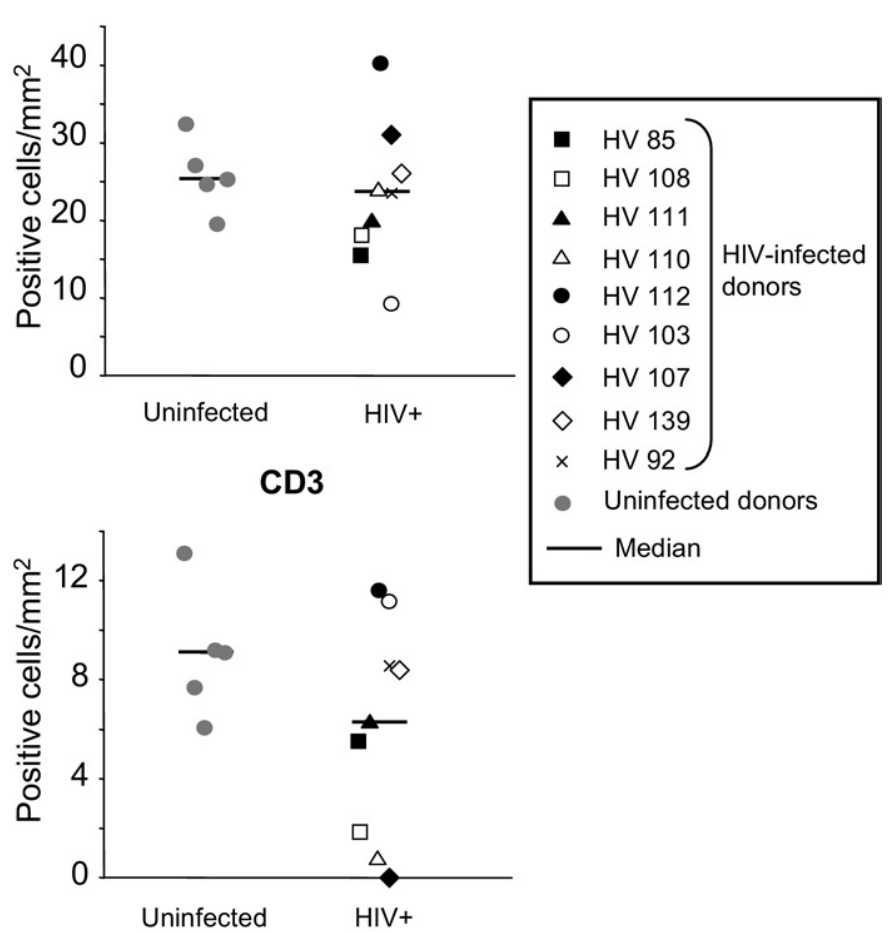

Figure 7. Quantification of $\mathrm{CD} 163^{+}, \mathrm{HLA}^{-\mathrm{DR}}{ }^{+}, \mathrm{CD}^{+}$, and $\mathrm{CD} 3^{+}$cells in seminal vesicles from uninfected versus HIV-infected men. The respective percentages of $\mathrm{CD} 163^{+}, \mathrm{HLA}_{-} \mathrm{DR}^{+}, \mathrm{CD}^{+}, \mathrm{CD}^{+}$, and $\mathrm{CD}^{+}$cells per surface unit were evaluated using immunohistochemistry in the seminal vesicles from a minimum of five uninfected donors and from nine HIV-infected men (Wilcoxon test, ${ }^{*} P<0.05$; control, uninfected).

secretory lumen. In contrast, no increase in reverse transcriptase activity or viral DNA was observed in seminal vesicle explants after exposure to the HIV-1 X $4_{\text {IIIB }}$ strain despite similar or higher viral stock titer to HIV R5 $5_{\mathrm{SF} 162}$, prolonged incubation with the virus, and longer culture period (data not shown). In agreement with this, the explant supernatants collected at various times during culture did not trigger productive infection of PBMCs, and infected cells were not detected using immunohistochemistry. HIV-1 X4 restriction has been reported for different organs in vitro and inferred to be either a low number of $\mathrm{CD}^{+}{ }^{+} \mathrm{CXCR} 4^{+}$target cells, ${ }^{33}$ unfavorable cytokine environment (eg, high level of the CXCR4 ligand SDF- $1^{36}$ ), or lack ${ }^{34}$ or suboptimal activation ${ }^{26}$ of $\mathrm{T}$ lymphocytes inducing post-entry block. In the seminal vesicles, the small number of $\mathrm{CD} 4^{+} \mathrm{CXCR} 4^{+} \mathrm{T}$ lymphocytes in the explants and the marked decrease in expression of the CXCR4 transcript during culture are likely involved in $\mathrm{X} 4$ restriction, although additional mechanisms cannot be ruled out. In the prostate gland, we have previously demonstrated a similar restriction of X4 strain replication. ${ }^{26}$ However, in that case, a different mechanism was probably involved because CXCR4 ${ }^{+}$cells and T lymphocytes outnumbered macrophages and $\mathrm{CCR}^{+}{ }^{+}$cells. ${ }^{26}$

R5 strains are selectively transmitted over X4 strains, which are rarely transmitted and are observed in only a subset of individuals later during the natural history of HIV. Therefore, X4 strains are selected against both during transmission and over the course of the disease by a range of potential mechanisms. ${ }^{37}$ Although $\mathrm{X} 4$ variants can sometimes be detected in semen, R5 viruses seem to predominate (reviewed by Duenas-Decamp et $\mathrm{al}^{38}$ ), which may reflect selective replication in the male genital tract organs. Whether the restriction for CXCR4-using variants occurs in the seminal vesicles and prostate gland in vivo remains to be determined. In addition, it is important to remember that the two prototypic strains used in the present study cannot reflect the full diversity observed for primary strains in terms of co-receptor usage and tropism. ${ }^{39}$ Hence, some CXCR4-dependent primary isolates can productively infect macrophages via CXCR4. ${ }^{40-42}$ In contrast, the prototypic $X 4_{\text {IIIB }}$ strain does not replicate in macrophages. ${ }^{41,42}$ Therefore, it cannot be excluded that a subset of $X 4$ strains may be able to replicate in the seminal vesicle resident macrophages. Furthermore, although HIV-1 R5 $5_{\mathrm{SF} 162}$ behaves similarly to primary macrophage-tropic R5 strains, ${ }^{43}$ not all CCR5using strains are macrophage-tropic (reviewed by Duenas-Decamp et $\mathrm{al}^{38}$ ).

Our observation of HIV infection of the seminal vesicles in vitro was confirmed in vivo via analysis of the seminal vesicle tissues from nine HIV-infected men. Of the seven men who tested positive for HIV RNA and protein in the seminal vesicles, five were receiving HAART, with an undetectable blood viral load at the last measurement before death (ie, between 1 week and 4 months), and two had prolonged suppression of viremia for up to 5 years. Although we cannot ascertain that in all of these men the viremia was still undetectable at the time of death, this suggests that the seminal vesicles may constitute a viral 
reservoir resistant to HIV eradication by antiretroviral therapy. Infected cells were primarily macrophages and, to a lesser extent, T lymphocytes. Chronically infected tissue macrophages are generally regarded as long-lived reservoirs in which reverse transcriptase inhibitors are ineffective and protease inhibitors demonstrate lower antiviral activity than in T lymphocytes. ${ }^{44,45}$ That productively infected $\mathrm{CD}^{+}{ }^{+} \mathrm{T}$ cells were detected in treated men could reflect poor penetration of the antiretroviral drugs in the seminal vesicles because infected activated T lymphocytes are short-lived and usually rapidly eliminated after HAART. ${ }^{46}$ Infected cells were observed either in the stroma, close to the epithelium, or in the lumen of the seminal vesicles (Figure 6D), which suggests that they could contribute to semen contamination. SIV-infected cells, $\mathrm{CD} 8^{+}$macrophages, and T cells have similarly been reported in the lumen of the seminal vesicles from macaques with AIDS. ${ }^{22,23}$ Quantitative analysis of the potential HIV target cells present in the seminal vesicles from HIV-infected men revealed a moderate but overall significant increase in macrophages, in agreement with previous observations in the seminal vesicles from macaques with AIDS. ${ }^{22,23}$ In contrast, the numbers of CD4 ${ }^{+}$ and $\mathrm{CD}^{+}$cells in HIV-infected men were not statistically different from those in uninfected donors. This differs from the increase in T lymphocytes reported in both macaques with $\operatorname{AIDS}^{22,23}$ and in asymptomatic macaques chronically infected and demonstrating a high blood viral load. ${ }^{15}$ In the latter, the HLA-DR ${ }^{+}$T-lymphocyte infiltrates were characterized as a mix of $\mathrm{CD}^{+}$and cytotoxic cells. ${ }^{15}$ However, the absence of a significant increase in $T$ lymphocytes in the seminal vesicles from the HIV-infected patients is in agreement with our previous findings in chronically infected macaques with both low viremia and low level of infection of the seminal vesicles, in which T-cell infiltrates were not observed. ${ }^{15}$ Thus, low viremia and/or low level of infection of the seminal vesicles in the HIV-infected patients receiving HAART may prevent infiltration of activated T lymphocytes. Of note, seven donors were co-infected with HCV and/or HBV, and one donor was additionally infected with human T-lymphotropic virus. HCV and HBV co-infection is relatively common, estimated to occur in 4 million to 5 million and 2 million to 4 million, respectively, of the 33 million persons infected with HIV worldwide. ${ }^{47}$ Whereas HIV increases HCV and $\mathrm{HBV}$ replication and has a negative effect on the progression of both HCV and HBV infection, ${ }^{48-51}$ the reverse remains unclear. ${ }^{48,50,52}$ For example, although HIV replication in co-infected patients may, in theory, be stimulated by the persistent state of immune activation induced by chronic HBV replication and by the HBV protein $\mathrm{HBx},{ }^{53}$ no significant effect of HBV carriage on HIV progression has been observed. ${ }^{50}$ After initiation of HAART, virologic and immunologic responses are generally similar in both HCV/HIV ${ }^{54,55}$ and HBV/HIV ${ }^{56-58}$ co-infected patients compared with those with HIV alone. Whether HBV, HCV, or human T-lymphotropic virus co-infection could influence seminal vesicle infection by HIV is currently unknown.

The potential sources of HIV in semen are local production within one or several of the male genital tract organs and tissues, ie, testes, epididymides, prostate, seminal vesicles, bulbourethral glands, and urethral tissue, and/or spillover from the blood. Although the oligoclonal amplification of blood viral strains evidenced in semen ${ }^{2}$ could reflect HIV replication in recently infiltrating activated immune cells in male genital tract organs, compartmentalization of HIV strains between blood and se$m^{2} n^{2}$ is likely due to prolonged viral replication under specific selective pressures in the immune resident cells of the male genital organs. We have previously demonstrated that the human testes ${ }^{18}$ and the inflammatory prostate with benign hyperplasia ${ }^{26}$ are infected in vitro with HIV and produce infectious particles. The level of reverse transcriptase activity and frequency of detection of infected cells seemed to be lower in the testes compared with the seminal vesicles and inflammed prostate gland. Similarly, in SIV-infected macaques in vivo, the testes consistently demonstrated lower levels of infection when compared with the accessory glands. ${ }^{15}$ This is likely due to the lower number of HIV target cells (ie, macrophages and $T$ lymphocytes) in both human and macaque testes when compared with the accessory glands. Vasectomy, which eliminates secretions from the testes, rete testes, epididymides, and proximal vasa deferentia, does not significantly alter the seminal viral load, ${ }^{14}$ which indicates that the testes and epididymides are not a major source of free virus in semen. Although vasectomy does not eliminate cell-associated HIV, ${ }^{14,59}$ its effect on the number of infected cells is difficult to assess because it artificially increases the detection of HIV in seminal cells by eliminating the dilution factor provided by the high number of noninfected spermatozoa in men who have not undergone vasectomy. Therefore, while the testes and epididymides do not seem to constitute an important source of free viral particles, their role as a source of infected cells in semen cannot be ruled out, in particular because the epididymides are an important source of leukocytes in semen. ${ }^{59,60}$ The concept that infected cells and viral particles in semen may arise from distinct genital organs is supported by several elements; thus, the detection of cell-free HIV RNA is not associated with that of cell-associated pro-viral DNA in semen, ${ }^{14}$ and subcompartmentalization of HIV quasispecies between seminal cells and seminal plasma has been evidenced. ${ }^{4,61}$ Whereas macrophage-tropic R5 strains are readily detected in cell-free seminal plasma, ${ }^{62}$ $T$ lymphocytes are the most commonly HIV-infected leukocytes in semen, ${ }^{63}$ and pro-viral DNA envelope sequences in seminal cells are primarily not macrophagetropic. ${ }^{64}$ This argues against a major contribution of the seminal vesicles to HIV-infected cells in semen because in vitro and in treated men, the bulk of infected cells in this organ is of macrophage nature. However, the situation may be different in HIV-positive men who have not received treatment, as suggested by the experience in macaques in which T cells infiltrating the seminal vesicles were observed. ${ }^{15}$ The levels of reverse transcriptase activity detected in the human seminal vesicle supernatants were higher than those in the testes and were in the same range as those we previously reported for an inflammed prostate exposed to the same virus strain and dosage. 
This suggests that the seminal vesicles could be a major contributor to HIV particles in semen, as has been hypothesized. ${ }^{21}$

The present study offers several perspectives including the following. First, the demonstration of infection of several human and macaque semen-producing organs in vitro and in vivo, together with evidence of organ-specific signatures in macaques, paves the way for studies with the objective of determining the respective contribution of these organs to semen contamination. Second, whether the seminal vesicles and/or other male genital tract organs produce some of the transmitted strains observed in acutely infected individuals remains to be determined. Third, the finding of HIV-infected cells in the seminal vesicles of HIV-infected men receiving HAART demands further studies to explore the reasons for this persistence. This is currently under investigation in our laboratory in SIV-infected macaques receiving HAART. That seminal vesicles host HIV and constitute potential reservoirs should be taken into account when new therapy approaches are considered.

\section{Acknowledgments}

The human seminal vesicles were provided by the $\mathrm{Na}$ tional Disease Research Interchange. We thank Christine Monfort for statistical analysis.

\section{References}

1. Royce RA, Sena A, Cates W Jr, Cohen MS: Sexual transmission of HIV. N Engl J Med 1997, 336:1072-1078

2. Anderson JA, Ping LH, Dibben O, Jabara CB, Arney L, Kincer L, Tang Y, Hobbs M, Hoffman I, Kazembe P, Jones CD, Borrow P, Fiscus S, Cohen MS, Swanstrom R: HIV-1 populations in semen arise through multiple mechanisms. PLoS Pathog 2010, 6:e1001053

3. Pillai SK, Good B, Pond SK, Wong JK, Strain MC, Richman DD, Smith DM: Semen-specific genetic characteristics of human immunodeficiency virus type 1 env. J Virol 2005, 79:1734-1742

4. Ghosn J, Viard JP, Katlama C, de Almeida M, Tubiana R, Letourneur F, Aaron L, Goujard C, Salmon D, Leruez-Ville M, Rouzioux C, Chaix ML: Evidence of genotypic resistance diversity of archived and circulating viral strains in blood and semen of pre-treated HIV-infected men. AIDS 2004, 18:447-457

5. Le Tortorec A, Dejucq-Rainsford N: HIV infection of the male genital tract: consequences for sexual transmission and reproduction. Int $J$ Androl 2010, 33:e98-e108

6. Halfon P, Giorgetti C, Khiri H, Penaranda G, Terriou P, Porcu-Buisson G, Chabert-Orsini V: Semen may harbor HIV despite effective HAART: another piece in the puzzle. PLoS One 2010, 5:e10569

7. Sheth PM, Kovacs C, Kemal KS, Jones RB, Raboud JM, Pilon R, la Porte C, Ostrowski M, Loutfy M, Burger H, Weiser B, Kaul R: Persistent HIV RNA shedding in semen despite effective antiretroviral therapy. AIDS 2009, 23:2050-2054

8. Marcelin AG, Tubiana R, Lambert-Niclot S, Lefebvre G, Dominguez S, Bonmarchand M, Vauthier-Brouzes D, Marguet F, Mousset-Simeon N, Peytavin G, Poirot C: Detection of HIV-1 RNA in seminal plasma samples from treated patients with undetectable HIV-1 RNA in blood plasma. AIDS 2008, 22:1677-1679

9. Pasquier CJ, Moinard N, Saune K, Souyris C, Lavit M, Daudin M, Izopet J, Bujan L: Persistent differences in the antiviral effects of highly active antiretroviral therapy in the blood and male genital tract. AIDS 2008, 22:1894-1896

10. Tachet A, Dulioust E, Salmon D, De Almeida M, Rivalland S, Finkielsztejn L, Heard I, Jouannet P. Sicard D, Rouzioux C: Detection and quantification of HIV-1 in semen: identification of a subpopulation of men at high potential risk of viral sexual transmission AIDS 1999, 13:823-831

11. Eron J, Vernazza PL, Johnston DM, Seillier-Moiseiwitsch F, Alcorn TM, Fiscus SA, Cohen MS: Resistance of HIV-1 to antiretroviral agents in blood and seminal plasma: implications for transmission. AIDS 1998, 12:F181-F189

12. Kroodsma KL, Kozal MJ, Hamed KA, Winters MA, Merigan TC: Detection of drug resistant mutations in the human immunodeficiency virus type 1 (HIV-1) pol gene: differences in semen and blood HIV-1 RNA and proviral DNA. J Infect Dis 1994, 170:1292-1295

13. Kiessling AA, Fitzgerald LM, Zhang D, Chhay H, Brettler D, Eyre RC, Steinberg J, McGowan K, Byrn RA: Human immunodeficiency virus in semen arises from a genetically distinct virus reservoir. AIDS Res Hum Retroviruses 1998, 14:S33-S41

14. Krieger JN, Nirapathpongporn A, Chaiyaporn M, Peterson G, Nikolaeva I, Akridge R, Ross SO, Coombs RW: Vasectomy and human immunodeficiency virus type 1 in semen. J Urol 1998, 159:820-825

15. Le Tortorec A, Le Grand R, Denis H, Satie AP, Mannioui K, Roques P, Maillard A, Daniels S, Jegou B, Dejucq-Rainsford N: Infection of semen-producing organs by SIV during the acute and chronic stages of the disease. PLoS One 2008, 3:e1792

16. Lau SK, Chu PG, Weiss LM: CD163: a specific marker of macrophages in paraffin-embedded tissue samples. Am J Clin Pathol 2004, 122:794-801

17. Nguyen TT, Schwartz EJ, West RB, Warnke RA, Arber DA, Natkunam Y: Expression of CD163 (hemoglobin scavenger receptor) in normal tissues, lymphomas, carcinomas, and sarcomas is largely restricted to the monocyte/macrophage lineage. Am J Surg Pathol 2005, 29 : 617-624

18. Roulet V, Satie AP, Ruffault A, Le Tortorec A, Denis H, Guist'hau O, Patard JJ, Rioux-Leclerq N, Gicquel J, Jegou B, Dejucq-Rainsford N: Susceptibility of human testis to human immunodeficiency virus-1 infection in situ and in vitro. Am J Pathol 2006, 169:2094-2103

19. Livak KJ, Schmittgen TD: Analysis of relative gene expression data using real-time quantitative PCR and the 2(-Delta Delta $C(T)$ ) method Methods 2001, 25:402-408

20. Walter BL, Wehrly K, Swanstrom R, Platt E, Kabat D, Chesebro B: Role of low CD4 levels in the influence of human immunodeficiency virus type 1 envelope $\mathrm{V} 1$ and $\mathrm{V} 2$ regions on entry and spread in macrophages. J Virol 2005, 79:4828-4837

21. Coombs RW, Lockhart D, Ross SO, Deutsch L, Dragavon J, Diem K, Hooton TM, Collier AC, Corey L, Krieger JN: Lower genitourinary tract sources of seminal HIV. J Acquir Immune Defic Syndr 2006, 41:430438

22. Miller CJ, Vogel P, Alexander NJ, Dandekar S, Hendrickx AG, Marx PA: Pathology and localization of simian immunodeficiency virus in the reproductive tract of chronically infected male rhesus macaques. Lab Invest 1994, 70:255-262

23. Baskerville A, Cook RW, Dennis MJ, Cranage MP, Greenaway PJ: Pathological changes in the reproductive tract of male rhesus monkeys associated with age and simian AIDS. J Comp Pathol 1992, 107:49-57

24. Nuovo GJ, Becker J, Simsir A, Margiotta M, Khalife G, Shevchuk M: HIV-1 nucleic acids localize to the spermatogonia and their progeny: a study by polymerase chain reaction in situ hybridization. Am J Pathol 1994, 144:1142-1148

25. Roulet V, Denis H, Staub C, Le Tortorec A, Delaleu B, Satie AP, Patard JJ, Jegou B, Dejucq-Rainsford N: Human testis in organotypic culture: application for basic or clinical research. Hum Reprod 2006, 21:1564-1575

26. Le Tortorec A, Satie AP, Denis H, Rioux-Leclercq N, Havard L, Ruffault A, Jegou B, Dejucq-Rainsford N: Human prostate supports more efficient replication of HIV-1 R5 than X4 strains ex vivo. Retrovirology 2008, 5:119

27. Anderson DJ, Pudney J: Human male genital tract immunity and experimental models. Mucosal Immunology, vol 2, ed 3. Edited by $J$ Mestecky, M Lamm, W Strober, J Bienenstock, J McGhee, L Mayer. New York, Elsevier Academic Press, 2005, pp 1647-1659

28. El-Dermiry M, Hargreave T, Busuttil A, James K, Ritchie A, Chrisholm G: Lymphocyte subpopulations in the male genital tract. $\mathrm{Br} \mathrm{J}$ Urol $1985,57: 769$

29. Bomsel M, Alfsen A: Entry of viruses through the epithelial barrier: pathogenic trickery. Nat Rev Mol Cell Biol 2003, 4:57-68 
30. Dorosko SM, Connor RI: Primary human mammary epithelial cells endocytose HIV-1 and facilitate viral infection of $\mathrm{CD}^{+}{ }^{+} \mathrm{T}$ lymphocytes. J Virol 2010, 84:10533-10542

31. Saba E, Grivel JC, Vanpouille C, Brichacek B, Fitzgerald W, Margolis L, Lisco A: HIV-1 sexual transmission: early events of HIV-1 infection of human cervico-vaginal tissue in an optimized ex vivo model. Mucosal Immunol 2010, 3:280-290

32. Fischetti L, Barry SM, Hope TJ, Shattock RJ: HIV-1 infection of human penile explant tissue and protection by candidate microbicides. AIDS 2009, 23:319-328

33. Patterson BK, Landay A, Siegel JN, Flener Z, Pessis D, Chaviano A, Bailey RC: Susceptibility to human immunodeficiency virus-1 infection of human foreskin and cervical tissue grown in explant culture. Am J Pathol 2002, 161:867-873

34. Greenhead P, Hayes P, Watts PS, Laing KG, Griffin GE, Shattock RJ: Parameters of human immunodeficiency virus infection of human cervical tissue and inhibition by vaginal virucides. J Virol 2000, 74: 5577-5586

35. Collins KB, Patterson BK, Naus GJ, Landers DV, Gupta P: Development of an in vitro organ culture model to study transmission of HIV-1 in the female genital tract. Nat Med 2000, 6:475-479

36. Agace WW, Amara A, Roberts Al, Pablos JL, Thelen S, Uguccioni M, Li XY, Marsal J, Arenzana-Seisdedos F, Delaunay T, Ebert EC, Moser $\mathrm{B}$, Parker CM: Constitutive expression of stromal derived factor-1 by mucosal epithelia and its role in HIV transmission and propagation. Curr Biol 2000, 10:325-328

37. Grivel JC, Shattock RJ, Margolis LB: Selective transmission of R5 HIV-1 variants: where is the gatekeeper?, J Transl Med 2010, 9(Suppl 1):S6

38. Duenas-Decamp MJ, Peters PJ, Repik A, Musich T, Gonzalez-Perez MP, Caron C, Brown R, Ball J, Clapham PR: Variation in the biological properties of HIV-1 R5 envelopes: implications of envelope structure, transmission and pathogenesis. Future Virol 2010, 5:435-451

39. Clapham PR, McKnight A: HIV-1 receptors and cell tropism. Br Med Bull 2001, 58:43-59

40. Simmons G, Reeves JD, McKnight A, Dejucq N, Hibbitts S, Power CA, Aarons E, Schols D, De Clercq E, Proudfoot AE, Clapham PR: CXCR4 as a functional coreceptor for human immunodeficiency virus type 1 infection of primary macrophages. J Virol 1998, 72:8453-8457

41. Yi Y, Rana S, Turner JD, Gaddis N, Collman RG: CXCR-4 is expressed by primary macrophages and supports CCR5-independent infection by dual-tropic but not T-tropic isolates of human immunodeficiency virus type 1. J Virol 1998, 72:772-777

42. Verani A, Pesenti E, Polo S, Tresoldi E, Scarlatti G, Lusso P, Siccardi $A G$, Vercelli D: CXCR4 is a functional coreceptor for infection of human macrophages by CXCR4-dependent primary HIV-1 isolates. J Immunol 1998, 161:2084-2088

43. Simmons G, Wilkinson D, Reeves JD, Dittmar MT, Beddows S, Weber J, Carnegie G, Desselberger U, Gray PW, Weiss RA, Clapham PR: Primary, syncytium-inducing human immunodeficiency virus type 1 isolates are dual-tropic and most can use either Lestr or CCR5 as coreceptors for virus entry. J Virol 1996, 70:8355-8360

44. Crowe S, Zhu T, Muller WA: The contribution of monocyte infection and trafficking to viral persistence, and maintenance of the viral reservoir in HIV infection. J Leukoc Biol 2003, 74:635-641

45. Aquaro S, Svicher V, Schols D, Pollicita M, Antinori A, Balzarini J, Perno CF: Mechanisms underlying activity of antiretroviral drugs in HIV-1-infected macrophages: new therapeutic strategies. J Leukoc Biol 2006, 80:1103-1110

46. Perelson AS, Neumann AU, Markowitz M, Leonard JM, Ho DD: HIV-1 dynamics in vivo: virion clearance rate, infected cell life-span, and viral generation time. Science 1996, 271:1582-1586

47. Alter MJ: Epidemiology of viral hepatitis and HIV co-infection. J Hepatol 2006, 44:S6-S9

48. Rotman $Y$, Liang TJ: Coinfection with hepatitis $C$ virus and human immunodeficiency virus: virological, immunological, and clinical outcomes. J Virol 2009, 83:7366-7374
49. Lin W, Weinberg EM, Tai AW, Peng LF, Brockman MA, Kim KA, Kim SS, Borges CB, Shao RX, Chung RT: HIV increases HCV replication in a TGF-beta1-dependent manner. Gastroenterology 2008, 134: 803-811

50. Benhamou Y: Hepatitis B in the HIV-coinfected patient. J Acquir Immune Defic Syndr 2007, 45(Suppl 2):S57-S65

51. Thio CL: Hepatitis $B$ and human immunodeficiency virus coinfection. Hepatology 2009, 49:S138-S145

52. Chen TY, Ding EL, Seage lii GR, Kim AY: Meta-analysis: increased mortality associated with hepatitis C in HIV-infected persons is unrelated to HIV disease progression. Clin Infect Dis 2009, 49:1605-1615

53. Gomez-Gonzalo M, Carretero M, Rullas J, Lara-Pezzi E, Aramburu J, Berkhout B. Alcami J, Lopez-Cabrera M: The hepatitis B virus X protein induces HIV-1 replication and transcription in synergy with T-cell activation signals: functional roles of NF-kappaB/NF-AT and SP1-binding sites in the HIV-1 long terminal repeat promoter. J Biol Chem 2001, 276:35435-35443

54. Fuping G, Wei L, Yang H, Zhifeng Q, Lingyan Z, Yanling L, Taisheng L: Impact of hepatitis $C$ virus coinfection on HAART in HIV-infected individuals: multicentric observation cohort. J Acquir Immune Defic Syndr 2010, 54:137-142

55. Rockstroh JK, Mocroft A, Soriano V, Tural C, Losso MH, Horban A, Kirk O, Phillips A, Ledergerber B, Lundgren J: Influence of hepatitis C virus infection on HIV-1 disease progression and response to highly active antiretroviral therapy. J Infect Dis 2005, 192:992-1002

56. Omland LH, Weis N, Skinhoj P, Laursen A, Christensen PB, Nielsen $\mathrm{HI}$, Moller A, Engsig F, Sorensen HT, Obel N: Impact of hepatitis B virus co-infection on response to highly active antiretroviral treatment and outcome in HIV-infected individuals: a nationwide cohort study. HIV Med 2008, 9:300-306

57. Konopnicki D, Mocroft A, de Wit S, Antunes F, Ledergerber B, Katlama C, Zilmer K, Vella S, Kirk O, Lundgren JD: Hepatitis B and HIV prevalence: AIDS progression, response to highly active antiretroviral therapy and increased mortality in the EuroSIDA cohort. AIDS 2005, 19:593-601

58. Law WP, Duncombe CJ, Mahanontharit A, Boyd MA, Ruxrungtham K, Lange JM, Phanuphak P, Cooper DA, Dore GJ: Impact of viral hepatitis co-infection on response to antiretroviral therapy and HIV disease progression in the HIV-NAT cohort. AIDS 2004, 18:1169-1177

59. Anderson DJ, Politch JA, Martinez A, Van Voorhis BJ, Padian NS, O'Brien TR: White blood cells and HIV-1 in semen from vasectomised seropositive men. Lancet 1991, 338:573-574

60. Olsen G, Shields J: Seminal lymphocytes, plasma and AIDS. Nature 1984, 309:116-117

61. Paranjpe S, Craigo J, Patterson B, Ding M, Barroso P, Harrison L, Montelaro R, Gupta P: Subcompartmentalization of HIV-1 quasispecies between seminal cells and seminal plasma indicates their origin in distinct genital tissues. AIDS Res Hum Retroviruses 2002, 18:12711280

62. Brown RJ, Peters PJ, Caron C, Gonzalez-Perez MP, Stones L, Ankghuambom C, Pondei K, McClure CP, Alemnji G, Taylor S, Sharp PM Clapham PR, Ball JK: Intercompartmental recombination of HIV-1 contributes to env intrahost diversity and modulates viral tropism and sensitivity to entry inhibitors. J Virol 2011, 85:6024-6037

63. Quayle AJ, Xu C, Mayer KH, Anderson DJ: T lymphocytes and macrophages, but not motile spermatozoa, are a significant source of human immunodeficiency virus in semen. J Infect Dis 1997, 176:960968

64. Peters PJ, Sullivan WM, Duenas-Decamp MJ, Bhattacharya J, Ankghuambom C, Brown R, Luzuriaga K, Bell J, Simmonds P, Ball J, Clapham PR: Non-macrophage-tropic human immunodeficiency virus type 1 R5 envelopes predominate in blood, lymph nodes, and semen: implications for transmission and pathogenesis. J Virol 2006 , 80:6324-6332 